\title{
Damage event analysis of vertical ground source heat pump systems in Germany
}

\author{
Paul Fleuchaus* ${ }^{*}$ and Philipp Blum
}

*Correspondence: paul.fleuchaus@kit.edu Institute of Applied Geosciences (AGW), Karlsruhe Institute of Technology (KIT), Kaiserstraße 12,

76131 Karlsruhe, Germany

\begin{abstract}
In recent years, some spectacular cases of damage occurred with vertical ground source heat pump (GSHP) systems in Germany. Broad media coverage attracted enormous public attention, with reports about land subsidence and ground uplifts causing severe damage to buildings. Consequently, sales of vertical GSHP systems have declined. The current study develops conceptual models illustrating the causes and effects of damage in relation to geological and hydrogeological settings. Our investigations revealed nine cases of serious damage in Germany, causing financial losses of more than 100 million Euros. In most cases, connection of aquifers by leaky annular space grouting was the main cause of damage. Guidelines to regulate the installation of vertical GSHP systems have been introduced successfully in all federal states. However, further risk minimisation strategies must be developed to restore the public's confidence in GSHP technology. Quality assurance and quality control measures should include in particular the optimisation of backfilling materials and increasing use of monitoring systems.
\end{abstract}

Keywords: Ground source heat pumps, Ground heaving, Staufen, Damage event analysis, Shallow geothermal energy

\section{Background}

The 195 countries participating in 2015 United Nations Climate Change Conference (COP 21) in Paris agreed on keeping the increase in global average temperature below $2{ }^{\circ} \mathrm{C}$ above pre-industrial levels. Decarbonisation of the energy sector is an important step towards the implementation of this agreement. Shallow geothermal energy plays an important role in increasing the share of renewable energy sources in the energy mix and helps significantly reduce $\mathrm{CO}_{2}$ emissions (Bayer et al. 2012; Blum et al. 2010; Sivasakthivel et al. 2012). After a rapid increase of newly installed systems at the beginning of the millennium, sales figures have been declining in Germany since 2008 (Fig. 1). The reasons are stricter approval procedures, declining oil and gas prices, and increasing investment costs (Blum et al. 2011; Grimm et al. 2014; Rumohr 2008). Temporal correlation between declining sales figures and the disclosure of failure events, however, indicates an increasing uncertainty of the population with respect to the GSHP technology.

Vertical GSHP systems are characterised by small space requirements and a good sustainability (Grimm et al. 2014; Hähnlein et al. 2013). Despite the advantages, installation 


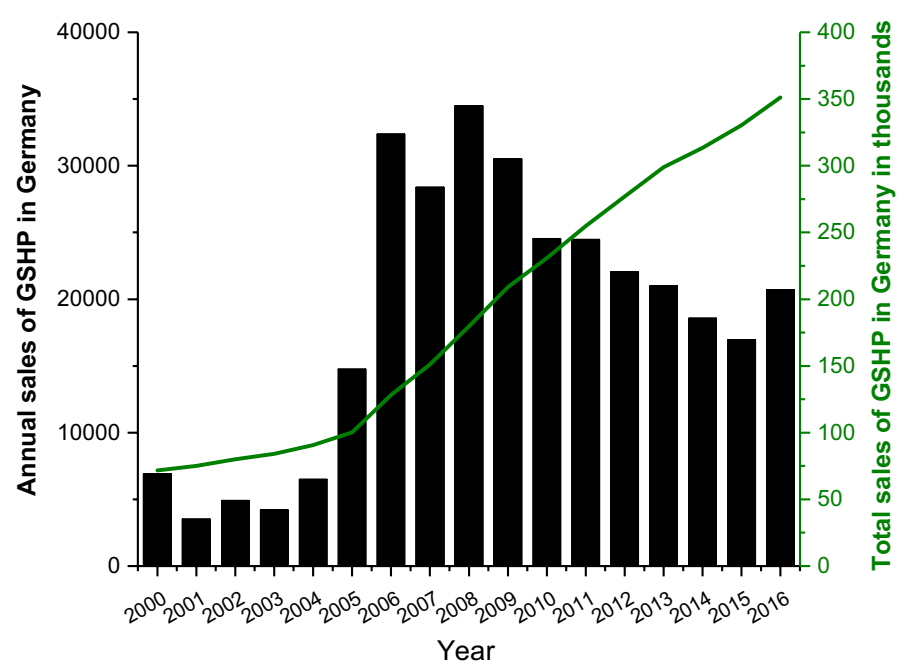

Fig. 1 Sales figures of GSHP systems in Germany (BWP 2016)

and usage of vertical GSHP systems entail certain risks such as (AD-HOC-AG Geologie 2011; Bassetti et al. 2006; Butscher et al. 2010; Grimm et al. 2014):

- Change in hydraulic, geophysical, and geochemical parameters caused by the hydraulic connection of separate aquifers.

- Soil settlements or dried-up wells due to falling groundwater levels (Grimm et al. 2014; Lowe 2012).

- Destabilising effect of ascending groundwater flows on the backfilling (AD-HOC-AG Geologie 2011).

- Flooding of adjacent buildings and infrastructure by artesian discharge.

- Swelling or subrosion processes of sulphate- and salt-bearing layers, leading to subsidence or ground uplifts.

- The formation of sinkholes or the loss of drilling equipment in karst areas (Butscher et al. 2010).

- Creation of new migration pathways for physical and chemical contaminants, such as organic anti-freeze liquids, diffusing chemicals in the backfilling material or contaminated drilling fluids (Klotzbücher et al. 2007; Santi et al. 2005).

- Potential hazards for drilling teams and residents due to near-subsurface gas reservoirs (Sachs and Eberhard 2010).

- High pollution vulnerability of groundwater in the area around contaminated sites.

According to the current industry report of the Federal Association of GSHP, sales figures will increase again until 2030, despite the population's loss of trust in the technology (BWP 2016). The expected sales upturn will be due to increased governmental subsidies for the installation of GSHP systems. In order to exploit the expected market momentum, minimising risks is of highest priority. Each subsurface activity affects the environment, and the probability of hazardous events increases with the number of drillings. Based on a previous study by Grimm et al. (2014), damage event analysis of 
vertical GSHP here is extended to cover entire Germany. The objective of the present study is to identify causes and effects of past damage events and to develop conceptual failure models considering local geological and hydrogeological subsurface conditions. Furthermore, occurrence probability of damage events in Germany is determined. Based on the analysis, we will discuss quality assurance measures for safer operation of vertical GSHP systems in the future.

\section{Methods}

So far, no official statistics on damages caused by GSHP systems in Germany have been published (Schäfer and Rumohr 2011). GSHP projects are legally approved of and controlled by local water authorities (Hähnlein et al. 2011). Damages that do not manifest on the surface or only occur long after the installation often remain undetected. Owners and drilling companies usually handle minor incidents among themselves. They often do not inform the responsible authority. Typically, local water authorities only consult State Geological Surveys (SGD) in specific cases, when a detailed cause-and-effect analysis is required (AD-HOC-AG Geologie 2011). Consequently, it is not possible to provide a reliable and comprehensive statement regarding the number of unreported damage events in Germany. Since information is provided in case of spectacular events only, this study focusses on cases with losses exceeding 500,000 Euros only.

Information on damage events was obtained from written enquiries to all federal geological surveys, from geological status reports, and from press releases. Additionally, the investigations of Grimm et al. (2014) provided a detailed overview of damage events during the drilling of borehole heat exchangers (BHE) in the state of Baden-Württemberg. The Geology AD-HOC Commission published a report on known impacts of shallow geothermal energy in Germany (AD-HOC-AG Geologie 2011). In this report, effects that are expected, accepted effects, and effects that occur unexpectedly are distinguished. Unexpected effects do not only include cases of high damage costs, but also impacts on the environment that cannot be quantified or temporary impacts, such as polluted water bodies or changed chemical and physical groundwater properties. Negative impacts most often refer to groundwater quality. In addition, there can be severe effects at the surface, such as ground uplifts, subsidence, or flooding.

In order to assess the hazard potential of future GSHP systems in relation to subsurface conditions, we developed cause-and-effect models for the cases of Staufen, Böblingen, Wiesbaden, and Kamen-Wasserkurl. These four damage cases are representative of the main geological and hydrogeological hazards in connection with drillings of BHE. Furthermore, the probability of occurrence $\left(W_{\text {damage }}\right)$ of serious damage events $(>500,000 €)$ was calculated using Eq. (1) (Grimm et al. 2014):

$$
W_{\text {damage }}=\frac{S_{\text {damage }}}{S_{\text {total }}} \times \frac{1}{t},
$$

where $S_{\text {damage }}$ defines the number of defective BHE, $S_{\text {total }}$ is the total number of installed BHE, and $t$ the period considered. 


\section{Serious damage events in Germany}

Table 1 lists and Fig. 2 illustrates all known cases of damage exceeding 500,000 Euros in Germany. The following section comprehensively analyses the cases of Staufen, Böblingen, Kamen-Wasserkurl, and Wiesbaden. The failure models of these four key events represent geological conditions and hydrogeological processes responsible for most damage events in Germany. Comprehensive understanding of subsurface processes helps identify potential hazards and prevent future damage events with vertical GSHP systems in Germany.

In September 2007, seven boreholes were drilled for heat supply of the historic town hall of the city of Staufen which is located in the southwest of Baden-Württemberg, in the tectonic transition zone between the Upper Rhine Graben and the Black Forest (Goldscheider and Bechtel 2009). Two weeks after the drillings, neighbouring residents

Table 1 Serious damage events (>500,000 Euros) of vertical GSHP projects in Germany

\begin{tabular}{|c|c|c|c|c|}
\hline Location & State & Year & $\begin{array}{l}\text { Damage in } \\
\text { million (Euros) }\end{array}$ & Causes and effects \\
\hline Wurmlingen & Baden-Württemberg & 2002 & $0.5-1$ & $\begin{array}{l}\text { Subrosion of sulphate-bear- } \\
\text { ing layers due to connec- } \\
\text { tion of aquifers resulting in } \\
\text { subsidence }\end{array}$ \\
\hline Rudersberg & Baden-Württemberg & 2007 & $1-10$ & $\begin{array}{l}\text { Ingress of ascending/ } \\
\text { descending groundwater } \\
\text { into anhydrite-bearing } \\
\text { layers resulting in ground } \\
\text { heaves at the surface }\end{array}$ \\
\hline Staufen & Baden-Württemberg & 2007 & $>50$ & $\begin{array}{l}\text { Ingress of ascending } \\
\text { groundwater into } \\
\text { anhydrite-bearing layers } \\
\text { resulting in ground heaves } \\
\text { at the surface }\end{array}$ \\
\hline Böblingen & Baden-Württemberg & 2008 & $>50$ & $\begin{array}{l}\text { Ingress of descend- } \\
\text { ing groundwater into } \\
\text { anhydrite-bearing layers } \\
\text { resulting in ground heaves } \\
\text { at the surface }\end{array}$ \\
\hline Schorndorf & Baden-Württemberg & 2008 & $1-10$ & $\begin{array}{l}\text { Connection of aquifers with } \\
\text { descending groundwater } \\
\text { potential due to a leaky } \\
\text { backfilling. Land subsid- } \\
\text { ence due to decreasing } \\
\text { groundwater level }\end{array}$ \\
\hline Kamen-Wasserkurl & North Rhine-Westphalia & 2009 & $1-10$ & $\begin{array}{l}\text { Drilling into karst structures. } \\
\text { Descending, vertical } \\
\text { groundwater flow, and } \\
\text { material transfer. Sinkhole } \\
\text { and subsidence at the } \\
\text { surface }\end{array}$ \\
\hline Wiesbaden & Hesse & 2009 & $0.5-1$ & $\begin{array}{l}\text { Tapping of an artesian } \\
\text { aquifer. Flooding at the } \\
\text { surface }\end{array}$ \\
\hline Leonberg & Baden-Württemberg & 2011 & $1-10$ & $\begin{array}{l}\text { Connection of aquifers with } \\
\text { descending groundwater } \\
\text { potential due to a leaky } \\
\text { backfilling. Land subsid- } \\
\text { ence due to decreasing } \\
\text { groundwater level }\end{array}$ \\
\hline Rottach-Egern & Bavaria & 2016 & $>0.5$ & $\begin{array}{l}\text { No specific causes are } \\
\text { identified yet }\end{array}$ \\
\hline
\end{tabular}




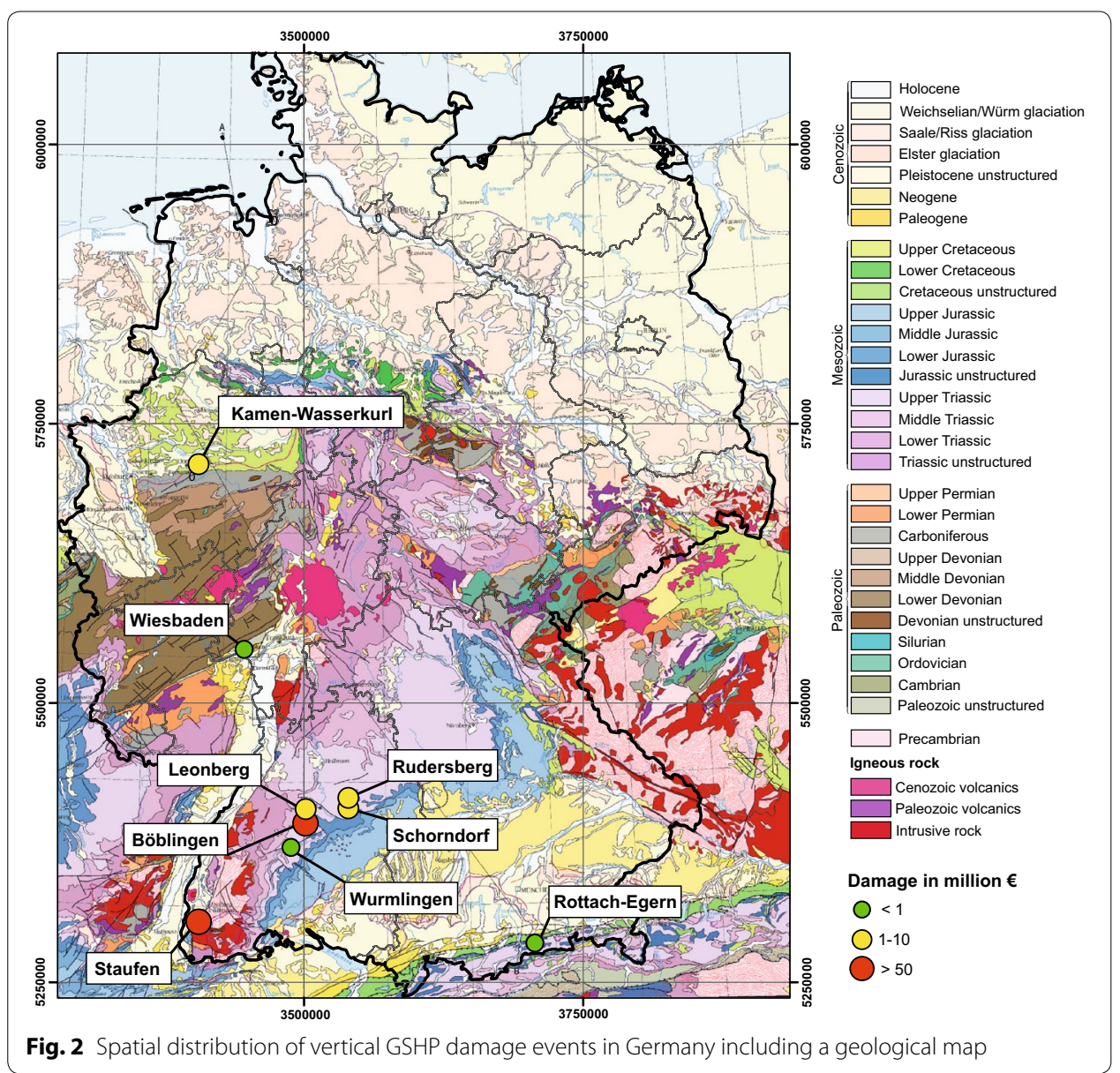

reported first cracks in their buildings, which rapidly propagated (Fig. 3b). In two published status reports, the Geological Survey of Baden-Württemberg (LGRB) provided evidence of the fact that these ground uplifts had been induced by the geothermal drillings (LGRB 2010, 2012). Initialisation of swelling processes by earthquakes was excluded (Sass and Burbaum 2012). With a final depth of $163 \mathrm{~m}$, the drillings penetrated the anhydrite-bearing Keuper formation. Anhydrite turns into gypsum when it comes into contact with water. The transformation process is accompanied by a volume increase of up to $61 \%$ (Butscher et al. 2016a).

The swelling process occurred relatively slowly due to its kinetics and medium-tolow hydraulic permeability in this zone (Sass and Burbaum 2010; Butscher et al. 2016b). The swellable anhydrite layers were located at a depth between 61.5 and $99.5 \mathrm{~m}$ below ground level. One of the seven drillings had intersected the basis of the Middle Keuper formation. A leaky backfilling created a hydraulic contact between the unconfined groundwater of the Lower Keuper formation and anhydrite-bearing layers (Fig. 4). Ascending groundwater found its way into swellable zones. In October 2016, geodetic measurements revealed a total uplift of $58 \mathrm{~cm}$ in the town hall area after a period of 8 years. Lateral displacement was measured to be $43 \mathrm{~cm}$ (Stadt Staufen 2016). The first remediation measures started in 2009, 2 years after first damages had been reported. 


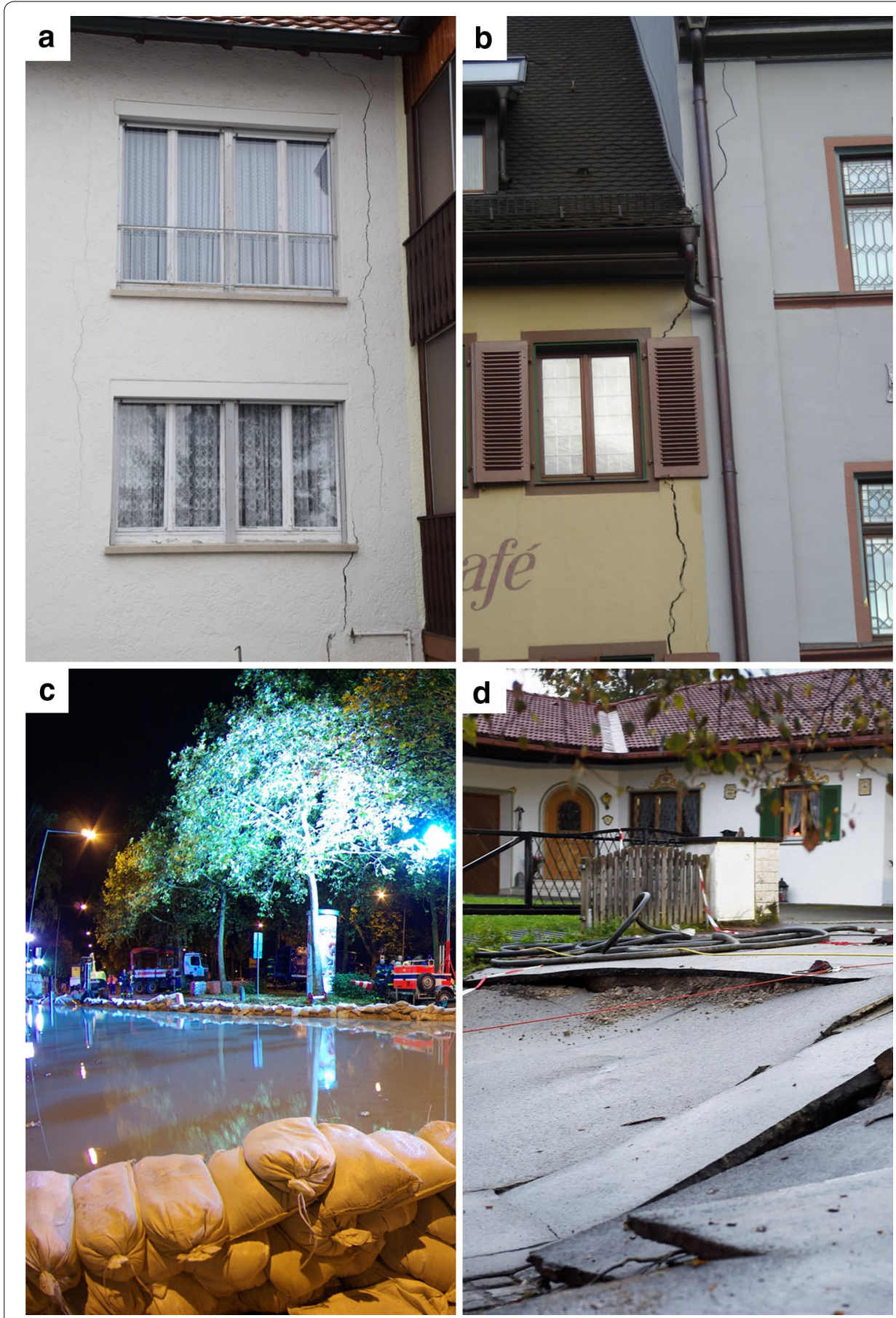

Fig. 3 Damages in Böblingen (a), Staufen (b), Wiesbaden (c), and Rottach-Egern (d). (:) a Paul Fleuchaus, b Christoph Butscher, c Michael Ehresmann, and $\mathbf{d}$ Thomas Plettenberg

These measures consisted in the suppression of the leaky backfilling and lowering of the groundwater level by pumping. The uplift rate was reduced from initially 11.0 to $3.5 \mathrm{~mm}$ per month. Since it is not possible to recover penetrated water from sulphate-bearing layers, swelling will stop only when there is no more inflow of groundwater (Ruch and Wirsing 2013). The uplift damaged more than 269 buildings (Sass and Burbaum 2010) 


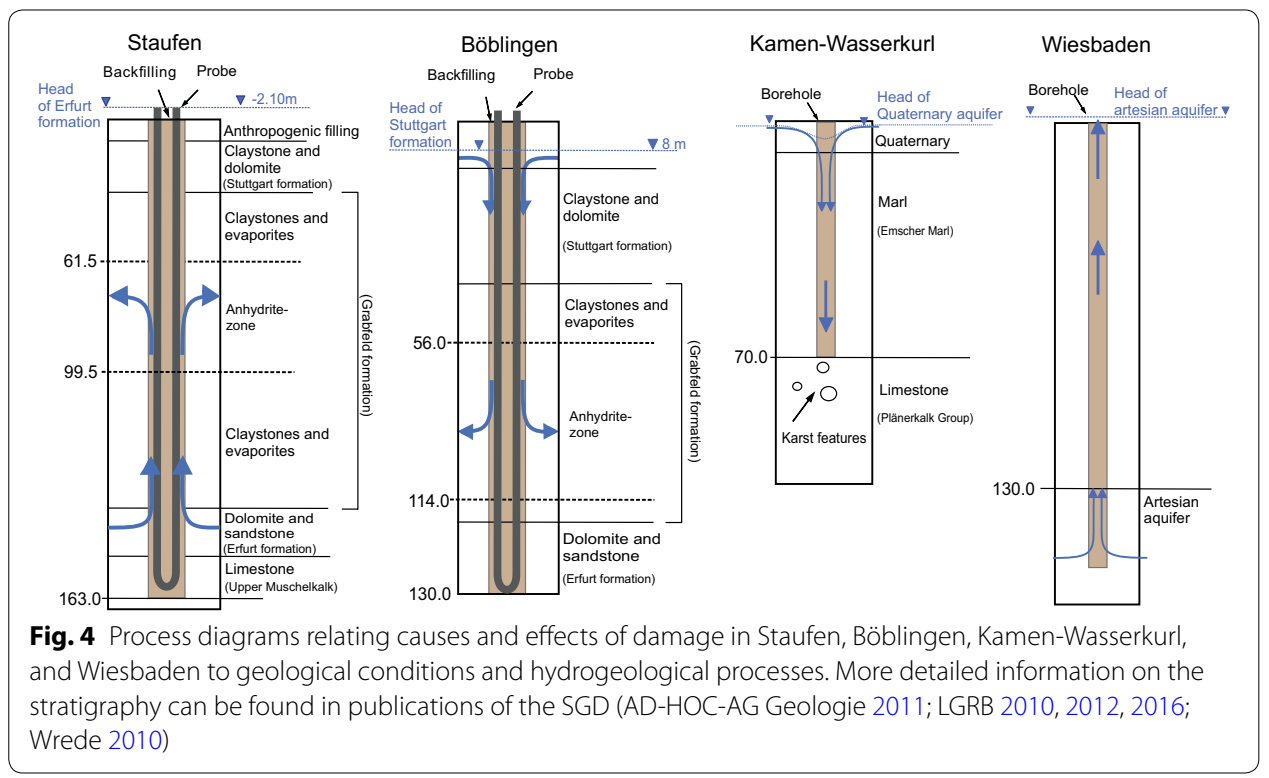

and the amount of damage is currently estimated to be over 50 million Euros (Stadt Staufen 2012).

In September 2008, two drillings were made for the installation of a vertical GSHP system in Böblingen, a town southwest of the state capital of Stuttgart. In late 2011, fine cracks appeared in the walls of several buildings (Fig. 3a). Geodetic measurements on behalf of the LGRB identified two uplift areas. In January 2014, the total uplift was measured to be $37-45 \mathrm{~cm}$ in the northern and $25-30 \mathrm{~cm}$ in the southern body after a period of 3 years (LGRB 2016).

To identify the cause of damage, the LGRB made several exploration drillings. Similar to the case of Staufen, inflow of groundwater into an anhydrite-bearing layer had caused the uplifts. The swellable anhydrite layers were located in the Grabfeld formation at a depth of 56-114 m below ground level (Fig. 4). Geothermal drillings reached their final depth in the impermeable Erfurt formation. Hence, upward migration of the underlying confined groundwater of the Upper Muschelkalk was excluded just as in the city of Staufen. Temperature profiles confirmed a descending groundwater flow from the Stuttgart formation into the anhydrite-bearing layers of the Grabfeld formation. Groundwater from the Stuttgart formation found its way through a leaky backfilling. In late 2014, the LGRB took first damage-limiting measures: Post-grouting of the leaky annulus with sulphate-resistant cement and permanent groundwater drawdown below the swellable zones. After this, the temperature profiles indicated a stop of vertical groundwater flow along the installed BHE. A reduced ground uplift rate was measured as soon as the initial recovery measures started (LGRB 2016). The uplift damaged more than 250 buildings and the amount of damage is currently estimated to be around 50 million Euros (StZ 2015).

In Kamen-Wasserkurl, in the state of North Rhine-Westphalia, a borehole was drilled for geothermal energy supply of a detached home in 2009. When drillings reached a depth of $70 \mathrm{~m}$, the drilling team stopped the work in the late afternoon. Later on the same day, a sinkhole formed around the drilling site. The sinkhole had a volume of 
50-60 $\mathrm{m}^{3}$ and buried the entire drilling equipment. On the following days, a land subsidence of up to $10 \mathrm{~cm}$ was measured up to a distance of $200 \mathrm{~m}$ from the drilling site. Cracks started to appear in adjacent buildings. Twenty neighbouring houses were damaged and four of them finally had to be demolished (AD-HOC-AG Geologie 2011). With a final depth of $70 \mathrm{~m}$, drillings had reached the transitional zone between the Emscher formation and the karstified Plänerkalk group (Fig. 4). The Emscher formation and particularly the Plänerkalk group are characterised by water-conducting faults that are interconnected with the karst system of the Plänerkalk group (AD-HOC-AG Geologie 2011). Low volumes of cuttings indicated a loss of drilling fluid during the drilling process already. The cuttings were flushed into the karst system by the drilling fluid. The loss of drilling fluid went unnoticed at the surface: groundwater flow from the quaternary aquifer into the borehole compensated the loss of drilling fluid. Groundwater flow was facilitated by the absence of an annulus casing. When the drilling team pulled out the pipes in the evening, groundwater flow was reinforced. With increasing flow velocities, large amounts of sediment were eroded and transported into the karst formation. A sinkhole formed around the uncased annulus. At a certain point, the material loss was balanced by a lateral mass transfer from the quaternary aquifer. This subrosion process led to subsidence in the surrounding area. The borehole was grouted with $750 \mathrm{~m}^{3}$ of cement in the following 3 months. The hydraulic sealing of the quaternary aquifer and the karst formation could be restored. The total amount of damage is presently estimated to be more than one million Euros (WN 2009).

In November 2009, drilling activities for a near-surface geothermal energy application on behalf of the Hessian Ministry of Finance induced flooding in the city centre of Wiesbaden. Drillings reached a depth of $130 \mathrm{~m}$ when a 7-m-high groundwater spring erupted from the borehole. Up to $6000 \mathrm{l} / \mathrm{min}$ of groundwater poured over a $400 \mathrm{~m}^{2}$ large area around the drilling site (Fig. 3c). Even though the borehole was filled with $56 \mathrm{~m}^{3}$ cement late at night, water discharge could not be stopped. New springs were formed in the vicinity of the borehole. At a depth of $130 \mathrm{~m}$, the exploration drilling hit an artesian aquifer (Fig. 4). With the discharging water, large amounts of loose material were flushed out of the ground. Due to potential subrosion processes, there was an increased hazard of land subsidence. Seismic follow-up investigations, however, did not show any irregularities in the subsurface. The costs of damage were estimated to be 500,000 Euros (FAZ 2010).

In October 2016, a borehole was drilled for the installation of a vertical GSHP system in Rottach-Egern (Bavaria). When drillings reached a depth of $45 \mathrm{~m}$, a 20-m-wide and 2-m-deep sinkhole started to appear (Fig. 3d). Only little information is available about the cause and processes of subsidence. According to first assumptions, drillings hit a groundwater-filled subsurface cavity. The cavity is a relic of a buried ice block formed by landslides during glacial periods (TS 2016). Damage is estimated to be 500,000 to one million Euros.

On the international level, hardly any information is available on damages caused by vertical GSHP systems. Similar to the cases of Staufen and Böblingen, anhydrite swelling damaged more than 100 historic houses in the town of Lochwiller, France. In Switzerland, Bassetti et al. (2006) reported several minor damages, such as subsidence or demolished probes. 


\section{Discussion}

Figure 5 presents the main causes and effects of vertical GSHP drillings in Germany. In $67 \%$ of all serious damage events, aquifers were connected by an incomplete and leaky backfilling of the BHE. This is not necessarily dangerous. However, an enhanced hazard potential results from specific geological and hydrogeological conditions: In three cases, the inflow of descending or ascending groundwater into anhydrite-bearing layers led to serious uplifts resulting in damages of houses and local infrastructure (e.g. Staufen, Böblingen, Rudersberg). In one case, drilling tapped an artesian aquifer and caused major flooding of adjacent streets (Wiesbaden). In five other cases, damages were caused by land subsidence: In Kamen-Wasserkurl, Wurmlingen, and Rottach-Egern, subrosion processes led to sinkholes or settlements at the surface. Aquifers with descending groundwater potential induced consolidation processes in Schorndorf and Leonberg.

In addition to the nine cases of damage exceeding 500,000 Euros described above, there were further cases with minor or non-quantifiable damage. These included flooded properties, polluted surface water bodies, dried-up wells, and changed chemical and physical groundwater properties (AD-HOC-AG Geologie 2011). However, there are no statistics about the frequency of such cases. According to a first estimation, the probability of damage with an amount of more than 500,000 Euros was calculated to be $0.0001 \%$ per year. This calculation is based on more than 350,000 installed GSHP systems in Germany over the last 26 years (Fig. 1 with data from BWP 2016). There are no official figures relating to the percentage of installed vertical systems out of the total number of installed GSHP. According to Walker-Hertkorn (personal communication 2017), the proportion of vertical systems is about $80 \%$.

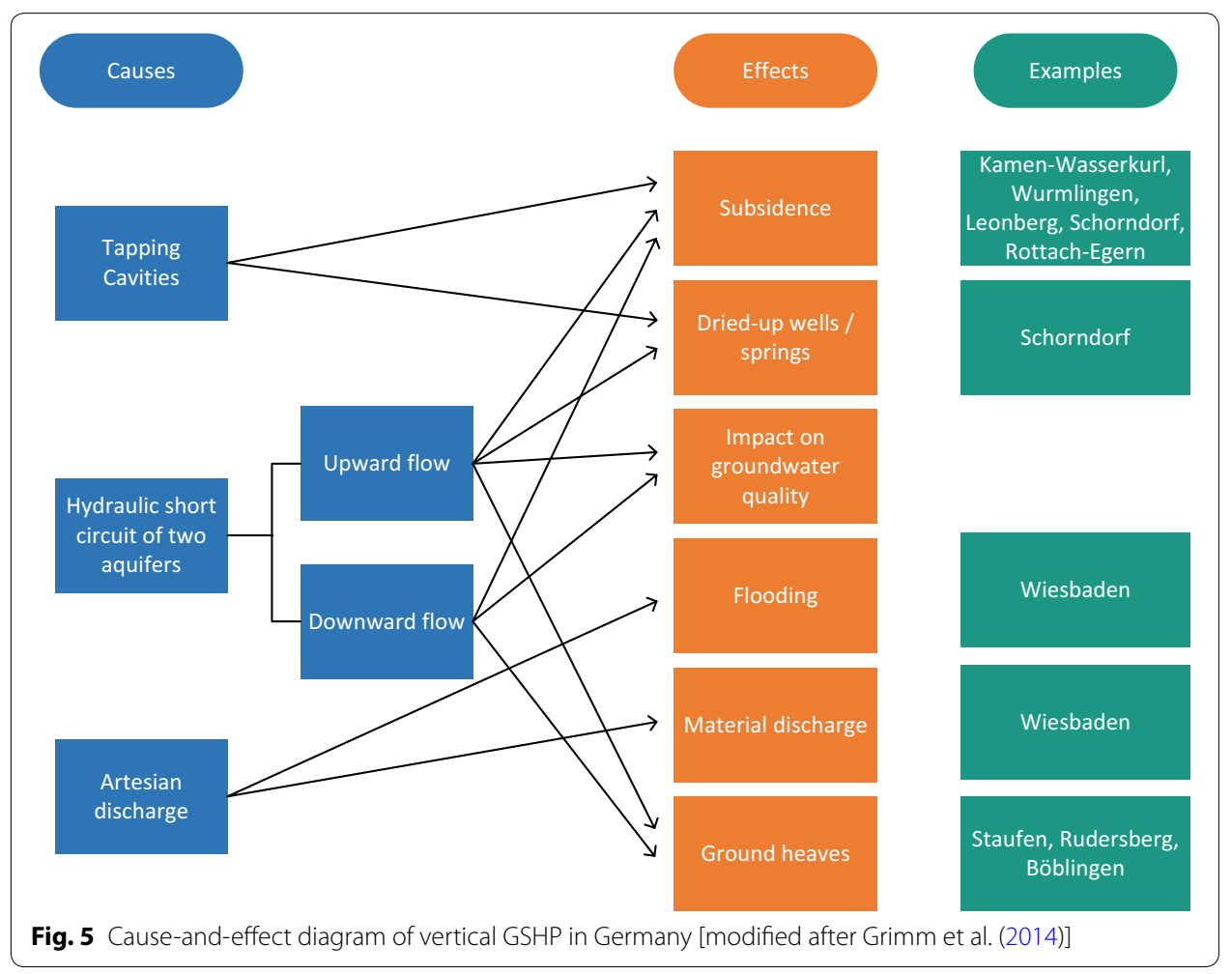


The probability of a serious damage is higher by a factor of 10 in Baden-Württemberg (Fig. 6), which is mainly caused by the specific geological and hydrogeological conditions of the Keuper-Muschelkalk transition. According to a first estimation, the probability of damage is increased by a factor of 40, when the drilling intersects this transition (Grimm et al. 2014). Except for the case of Kamen-Wasserkurl, damages in the amount of millions were entirely linked to the presence of swellable minerals in the underground (Fig. 4).

In general, usage and installation of vertical GSHP systems in Germany can be considered fairly safe compared to other technologies. Figure 6 compares the probability of a serious damage event of vertical GSHP with the probability of dying from air pollution caused by coal-fired plants in Germany [0.003\% per year (Grimm et al. 2014)] and the probability of a serious accident at a nuclear reactor worldwide $[0.02 \%$ per year (Grimm et al. 2014)]. Even though the idea of this comparison is to emphasis the low probability of serious damage events in Germany, the higher energy output of fossil-based energy sources is obvious.

As a consequence of hard coal mining, 35,000 claims for damages are made annually against the RAG AG, the largest German coal mining corporation (RAG 2014). Although 90\% of these claims are below 5000 Euros, the lifecycle costs of anthracite coal mines are estimated to be 13 billion Euros (RAG-Stiftung 2015). Even though the probability of serious damage events of vertical GSHP systems in Germany is rather low, such cases have to be prevented to restore public confidence in this renewable energy technology.

In Germany, standardised mining and water law approval procedures for vertical GSHP systems exist neither on the national, nor on the state level (Kübert et al. 2009). There is no specific law that governs the handling of shallow geothermal energy in Germany. Legal frameworks are derived from the Water Act and the Mining Act (Hähnlein et al. 2011). Guidelines adopted by each federal state complement the legal provisions

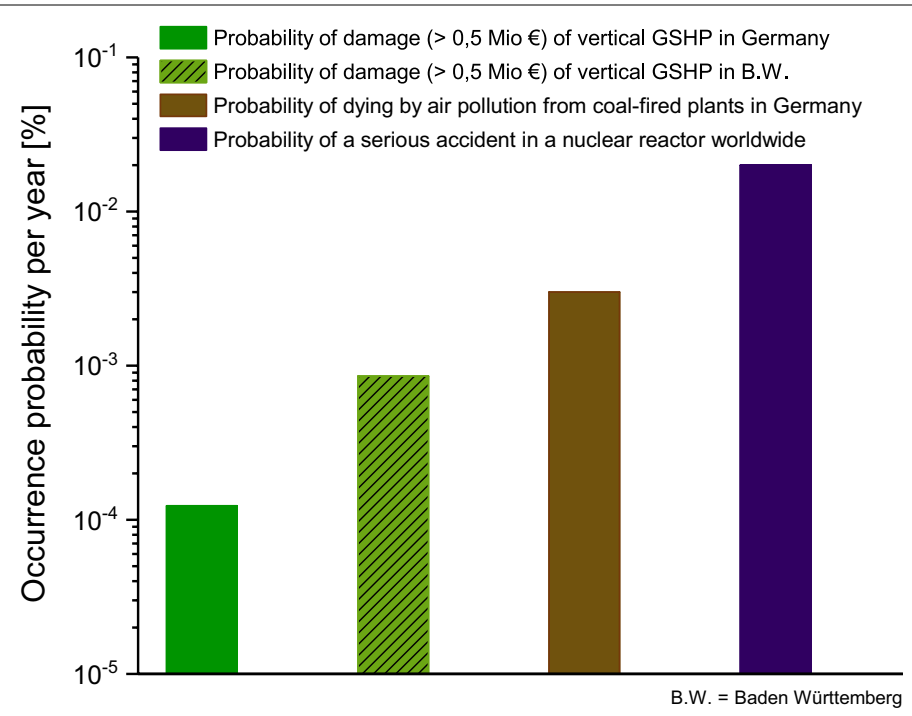

Fig. 6 Probability of occurrence per year of damage events in the amount of more than 500,000 Euros in Germany in comparison with two other non-geothermal probabilities, such as dying by air pollution and serious accident at a nuclear reactor worldwide 
(BVG 2014). Kübert et al. (2009) highlighted the differences of approval procedures between the federal states and national states (Hähnlein et al. 2011). Legal regulations differ considerably from state to state. The state of Baden-Württemberg reacted to the damage events by taking measures to assure quality as outlined in the "guidelines for quality assurance of downhole borehole heat exchangers" (LQS EWS 2011). For example, these guidelines require proof of suitability of the backfilling material used by an accredited institution. In case of confined groundwater conditions, packer systems have to be on hand to prevent uncontrolled groundwater discharge. Drilling depth is limited in case of anhydrite-bearing layers in the subsurface. Also material, technical, and anthropogenic issues are considered. The LQS EWS guidelines introduced have already proven their effectiveness: In all cases of damage known in Baden-Württemberg, the BHE had been installed prior to the publication of the LQS EWS.

The LQS EWS demonstrated the importance of considering regional boundary conditions when implementing national laws. Butscher et al. (2010) presented a risk-oriented approach to the approval of BHE in the Canton of Basel-Landschaft, Switzerland. It is important to also consider local and specific risks during the approval process. Hence, all geological, hydrogeological, geotechnical, and anthropogenic hazards have to be identified. By integrating all factors into a geographic information system (GIS), authorities, drilling companies, and owners are able to estimate the hazard potential of each project. In most federal states, such a GIS has already been established (e.g. Ondreka et al. 2007). The "information system on shallow geothermal energy in Baden-Württemberg (ISONG)" launched by the LGRB is a successful example: the online map does not only show water protection areas, but also warns of confined aquifers as well as geological difficulties. The Leibniz Institute for Applied Geophysics is also setting up an internet-based information system of geothermal resources for the entire country (Schulz et al. 2007). Currently, this effort focusses on providing information about geothermal potentials. Possible risks are not yet displayed. The project "Shallow Geothermal Energy Planning, Assessment and Mapping Strategies in Central Europe (GeoPLASMA-CE)" generates a cross-national web-based platform, which provides tools to support decision making and enables a visualisation of geothermal potentials and risks of conflicts. Based on current projects, a platform for comprehensive information on potential geological risks is expected to be established in the future.

To prevent future damage, qualitative improvement of applied materials and working processes must have priority. The Hydrogeology AD-HOC Committee has developed a range of quality assurance measures and published them in a technical report (ADHOC-AG Hydrogeologie 2015). Different drilling methods, frost resistance and longevity of backfilling materials, and several monitoring systems were tested. Furthermore, Solites, Karlsruhe Institute of Technology, and the EIFER Institute conduct research for the development of vertical GSHP systems within the framework of the EWS-tech project (Riegger et al. 2016). They chose a three-stage approach of laboratory, small-scale, and real-scale experiments. Based on the outcome of the experiments, recommendations for improved grouting of BHE are made, which can also be included in official guidelines. Thus, laboratory test criteria and test criteria for on-site use were developed. Building on the knowledge gained with respect to the long-term stability of backfillings, the damage potential of already existing BHE can be also assessed. 
In Germany, there is only little information available on hazards to groundwater. The impact of vertical GSHP systems on groundwater and the resulting impairments are difficult to estimate and damage most often cannot be quantified (AD-HOC-AG Geologie 2011). Contaminations often occur for a short period of time only or even remain undetected. Drilling companies and owners do not have any interest in and authorities often do not have enough resources for expensive monitoring measures or on-site inspections. Moreover, risks associated with groundwater usually become apparent only, if the water is used as drinking water (Butscher et al. 2010). Negative impacts of shallow geothermal energy on groundwater quality were the subject of many studies: Bonte et al. (2011) distinguished impacts of thermal, chemical, microbiological, and hydrological nature. According to Hähnlein et al. (2013), however, the existing knowledge is insufficient to assess the environmental impact on groundwater. Hence, there is a need for further environmental impact research and assessments through field and in situ experiments (Brielmann et al. 2011; Hähnlein et al. 2013).

In some cases, insufficient preliminary investigations, the use of improper materials, or poor decision making facilitated damage events in the past. Minimising risks includes not only the adoption of guidelines, but also the verification of compliance on construction sites. According to Sonnenfroh (personal communication 2017), about 10\% of their drilling activities are inspected by the local water authorities, which appears to be appropriate. Hence, we strongly recommend countrywide, regular on-site quality controls (QC) of on-site operations of drilling companies and plumbers to verify compliance with existing guidelines.

\section{Conclusion}

Events with a damage amount of more than 500,000 Euros are rare in Germany. In most cases, these damages were caused by aquifers that were connected by incomplete and leaky backfilling. Damages running into the millions were almost entirely caused by swellable minerals at the Keuper-Muschelkalk boundary. Due to the difficult geological and hydrogeological conditions in Baden-Württemberg, the probability of a damage event here is increased. As a countermeasure, the state of Baden-Württemberg has introduced the guideline "Leitlinien Qualitätssicherung Erdwärmesonde" (LQS EWS 2011, Guidelines for quality assurance of downhole borehole heat exchangers). Since then, no further damage events have occurred in Baden-Württemberg. Additionally, Harter et al. (2017) published an information flyer, where they clear up with 21 misunderstandings regarding GSHP systems. In order to prevent damage even more effectively in the future, the following activities are proposed:

\section{Systematic quantification of damage events in Germany}

Drilling companies or owners should be obliged to report damages directly to the responsible authority. Systematic and central collection of those data would reveal important information on the efficiency of quality assurance (QA) and quality control (QC) measures. Additionally, the probability of occurrence could be calculated in relation to geological and hydrogeological conditions. The population's confidence in vertical GSHP systems can only be restored by transparent damage reporting. Only exact and reliable statistics can prove the low hazard potential of this technology. 


\section{Ongoing development of GIS}

In order to assess various risks, comprehensive information on potential geological and hydrogeological hazards is required. The development of countrywide hazard maps should be given a high priority. Using precise GIS, a local specific, risk-oriented approval procedure can be established.

\section{Training of decision makers and staff}

Authorities and drilling companies should be able to make well-founded decisions in the process of planning, authorising, and executing GSHP projects, which include:

- Foresighted planning under careful consideration of geological and hydrogeological conditions.

- Quality-oriented and quality-controlled construction using site-specific materials and methods with a comprehensive documentation of all production steps and proper and continuous maintenance (Sass et al. 2014).

- Drilling teams should be able to recognise potential hazards in order to immediately take appropriate countermeasures.

\section{Regional and hazard-specific guidelines}

Building on the success achieved, state guidelines have to be adapted to take latest knowledge and methods into consideration. Intensive information exchange between all parties on relevant experiences and best practices would be desirable. Instead of 16 different guidelines for each federal state, authorities should focus on adopting cross-border, risk-specific, national standardised guidelines. Preliminary investigations, approval procedures, and specific requirements could be adapted to local conditions.

In high-risk areas, vertical GSHP systems should be subject to strict quality measures or approval might be refused. Despite all potential risks, however, it would be not in the public interest to restrict the use of a technology that undoubtedly has economic and ecological benefits just because of previous (unnecessary) damage events. Thus, crossborder quality assurance has to be given highest priority. Negative impacts on groundwater and its quality should be investigated in detail in the laboratory and in the field. Especially the quality of backfilling materials and backfilling procedure, appropriate monitoring systems, and appropriate drilling techniques have to be improved.

\section{Authors' contributions}

PF and PB designed the study and developed the methodology. PF drafted the final manuscript. PB offered supervision for the research and guidance with the interpretation of results. All authors read and approved the final manuscript.

\section{Acknowledgements}

We would like to thank Manuel Grimm for his comments and suggestions supporting our efforts. The constructive comments of two anonymous reviewers are also gratefully acknowledged.

\section{Competing interests}

The authors declare that they have no competing interests.

Availability of data and materials

All relevant data and material are presented in the main paper.

\section{Publisher's Note}

Springer Nature remains neutral with regard to jurisdictional claims in published maps and institutional affiliations. 
Received: 11 April 2017 Accepted: 20 June 2017

Published online: 29 June 2017

\section{References}

AD-HOC-AG Geologie. Fachbericht zu bisher bekannten Auswirkungen geothermischer Vorhaben in den Bundesländern. Staatliche geologische Dienste Deutschlands, Wiesbaden; 2011.

AD-HOC-AG Hydrogeologie. Empfehlungen für die Anforderungen an die hydraulische Durchlässigkeit des Systems Erdwärmesonde. Staatliche geologische Dienste Deutschlands; 2015.

Bassetti S, Rohner E, Signorelli S. Dokumentation von Schadensfällen bei Erdwärmesonden. EnergieSchweiz; 2006.

Bayer P, Saner D, Bolay S, Rybach L, Blum P. Greenhouse gas emission savings of ground source heat pump systems in Europe: a review. Renew Sustain Energy Rev. 2012;16(2):1256-67. doi:10.1016/j.rser.2011.09.027.

Blum P, Campillo G, Kölbel T. Techno-economic and spatial analysis of vertical ground source heat pump systems in Germany. Energy. 2011;36(5):3002-11. doi:10.1016/j.energy.2011.02.044.

Blum P, Campillo G, Münch W, Kölbel T. $\mathrm{CO}_{2}$ savings of ground source heat pump systems - a regional analysis. Renew Energy. 2010;35(1):122-7. doi:10.1016/j.renene.2009.03.034.

Bonte M, Stuyfzand PJ, Hulsmann A, van Beelen P. Underground thermal energy storage: environmental risks and policy developments in the Netherlands and European Union. Ecol Soc. 2011;16:22.

Brielmann H, Lueders T, Schreglmann K, Ferraro F, Avramov M, Hammerl V, Blum P, Bayer P, Griebler C. Oberflächennahe Geothermie und ihre potenziellen Auswirkungen auf Grundwasserökosysteme. Grundwasser. 2011; (16): 77-91.

Butscher C, Breuer S, Blum P. Swelling laws for clay-sulfate rocks revisited. Bull Eng Geol Environ. 2016a;63:707. doi:10.1007/s10064-016-0986-Z.

Butscher C, Huggenberger P, Auckenthaler A, Bänninger D. Risikoorientierte Bewilligung von Erdwärmesonden. Grundwasser. 2010; 16(1): 13-24. doi: 10.1007/s00767-010-0154-5.

Butscher C, Mutschler T, Blum P. Swelling of clay-sulfate rocks: a review of processes and controls. Rock Mech Rock Eng. 2016b;49(4):1533-49. doi:10.1007/s00603-015-0827-6.

BVG. Richtlinien und Leitfäden zur Oberflächennahen Geothermie. 2014. http://www.geothermie.de/service/publikationen/leitfaeden-und-richtlinien-der-bundeslaender.html. Accessed 9 Apr 2016.

BWP. Trotz Ölpreisverfall: Wärmepumpenabsatz 2015 stabil; 2016.

FAZ. Erdwärme-Bohrpanne kostet halbe Million Euro. Frankfurter Allgemeine Zeitung 2010; 2010.

Goldscheider N, Bechtel TD. Editors' message: the housing crisis from underground-damage to a historic town by geothermal drillings through anhydrite, Staufen, Germany. Hydrogeol J. 2009;17(3):491-3. doi:10.1007/ s10040-009-0458-7.

Grimm M, Stober I, Kohl T, Blum P. Schadensfallanalyse von Erdwärmesondenbohrungen in Baden-Württemberg. Grundwasser. 2014; 19(4): 275-286. doi: 10.1007/s00767-014-0269-1.

Hähnlein S, Bayer P, Ferguson G, Blum P. Sustainability and policy for the thermal use of shallow geothermal energy. Energy Policy. 2013;59:914-25. doi:10.1016/j.enpol.2013.04.040.

Hähnlein S, Blum P, Bayer P. Oberflächennahe Geothermie-aktuelle rechtliche Situation in Deutschland. Grundwasser. 2011;16(2):69-75. doi:10.1007/s00767-011-0162-0.

Harter K, Lorinser B, Sawillion M, Stober I. Erdwärmesonden: Erdwärme erfolgreich nutzen! 21 Missverständnisse. Ministerium für Umwelt, Klima und Energiewirtschaft Baden-Württemberg; 2017.

Klotzbücher T, Kappler A, Straub KL, Haderlein SB. Biodegradability and groundwater pollutant potential of organic anti-freeze liquids used in borehole heat exchangers. Geothermics. 2007;36(4):348-61. doi:10.1016/j. geothermics.2007.03.005.

Kübert M, Walker-Hertkorn S, Blum P, Bayer P, Hähnlein S. Praktische Hinweise zur Genehmigungspraxis der thermischen Nutzung des Untergrundes. bbr Sonderheft Geothermie: 8-13; 2009.

LGRB. Geologische Untersuchungen von Baugrundhebungen im Bereich des Erdwärmesondenfeldes beim Rathaus in der historischen Altstadt von Staufen i. Br; 2010.

LGRB. Zweiter Sachstandsbericht zu den seit dem 01.03.2010 erfolgten Untersuchungen im Bereich des Erdwärmesondenfeldes beim Rathaus in der historischen Altstadt von Staufen i. Br. Landesamt für Geologie, Rohstoffe und Bergbau Baden-Württemberg; 2012.

LGRB. Geologische Untersuchungen von Baugrundhebungen im nordöstlichen Stadtgebiet von Böblingen (Hebungsgebiet "Nord"): Sachstandsbericht. Landesamt für Geologie, Rohstoffe und Bergbau Baden-Württemberg; 2016.

Lowe M. Subsidence in sedimentary basins due to groundwater withdrawal for geothermal energy development. Utah Geol Survey. 2012.

LQS EWS. Leitlinien Qualitätssicherung Erdwärmesonden (LQS EWS). Ministerium für Umwelt, Klima und Energiewirtschaft Baden-Württemberg, Stuttgart; 2011.

Ondreka J, Rüsgen MI, Stober I, Czurda K. GIS-supported mapping of shallow geothermal potential of representative areas in south-western Germany_possibilities and limitations. Renew Energy. 2007;32(13):2186-200. doi:10.1016/j. renene.2006.11.009.

RAG. Glück auf. Zukunft: Nachhaltig handeln_Die RAG stellt Umwelt, Wirtschaft und Soziales in den Fokus. 2014. https:// www.rag.de/fileadmin/rag_de/user_upload/DOKUMENTE-DWNLD/Downloads_Publikationen/2014_10_06_ Glueck auf Zukunft.pdf. Accessed 24 Jan 2017.

RAG-Stiftung. Ewigkeitsaufgaben. 2015. http://www.rag-stiftung.de/ewigkeitsaufgaben/. Accessed 8 Mar 2016.

Riegger M, Rolker J, Stober I, Haist M, Schlager P, Zorn R, Huttenloch P, Steger H, Eckhardt J-D, Zemann M. EWS-tech: Weiterentwicklung der Erdwärmesonden-Technologie; 2016.

Ruch C, Wirsing G. Erkundung und Sanierungsstrategien im Erdwärmesonden-Schadensfall Staufen i. Br. geotechnik. 2013; 36(3):147-159. doi: 10.1002/gete.201300005. 
Rumohr S. Nutzung der Oberflächennahen Geothermie in Hessen - Ist das Ende des Booms erreicht? Hessisches Landesamt für Umwelt und Geologie, Wiesbaden; 2008.

Sachs O, Eberhard M. Erdgasausbruch bei einer Erdwärmesondenbohrung in Rothrist-Buchrain—ein Erfahrungsbericht. Swiss Bull. angewandte Geowissenschaften. 2010; 15(1): 43-51.

Santi PM, McCray JE, Martens JL. Investigating cross-contamination of aquifers. Hydrogeol J. 2005;14(1):51-68. doi:10.1007/s10040-004-0403-8.

Sass I, Brehm D, Coldewey WG, Dietrich J, Klein R, Kellner T, Kirschbaum B, Lehr C, Marek A, Mielke P. Empfehlung Oberflächennahe Geothermie_-Planung, Bau, Betrieb und Überwachung-EA Geothermie. Berlin: Ernst \& Sohn; 2014.

Sass I, Burbaum U. Damage to the historic town of Staufen (Germany) caused by geothermal drillings through anhydritebearing formations. AC. 2012. doi:10.3986/ac.v39i2.96.

Sass I, Burbaum U. Geothermische Bohrungen in Staufen im Breisgau: Schadensursachen und Perspektiven. geotechnik. 2010; 35(3): 198-205. doi: 10.1002/gete.201100018

Schäfer I, Rumohr S. Sichere Erdwärmeprojekte durch Geofachdaten. bbr Fachmagazin für Brunnen- und Leitungsbau, Sonderheft Oberflächennahe Geothermie:6-12; 2011.

Schulz R, Agemar T, Alten J-A, Wirth LW. Development of an Internet based geothermal information system for Germany. Erdöl Erdgas Kohle; 2007.

Sivasakthivel T, Murugesan K, Sahoo PK. Potential reduction in $\mathrm{CO}_{2}$ emission and saving in electricity by ground source heat pump system for space heating applications-a study on Northern Part of India. Procedia Eng. 2012;38:970-9. doi:10.1016/j.proeng.2012.06.123.

Stadt Staufen. Presseerklärung vom 17. September 2012 der Stadt Staufen und der Interessengemeinschaft der RissGeschädigten GbR (IGR); 2012.

Stadt Staufen. Presseerklärung zu den Hebungsrissen; 2016

StZ. Erdhebungen: Wasserrohre gehen zu Bruch: Böblingen: Stadt und Stadtwerke melden Schäden. Stuttgarter Zeitung; 2015

TS. Toteis-Theorie in der Lindenstraße. 2016. http://tegernseerstimme.de/toteis-theorie-in-der-lindenstrasse/225969.html Accessed 31 Mar 2017

Wrede V. Die Bohrungshavarie Kamen-Wasserkurl aus geowissenschaftlicher Sicht. In: Frenz W, Preuße A (eds) Geothermie-Risikobeherrschung und Stand der Technik, Perspektiven und Fördermöglichkeiten: 12. Aachener Altlastenund Bergschadenkundliches Kolloquium; GDMB, Clausthal-Zellerfeld 123; 2010.

WN. Boden tat sich auf: Millionenschaden nach Erdwärme-Bohrung. Westfälische Nachrichten; 2009.

\section{Submit your manuscript to a SpringerOpen ${ }^{\circ}$ journal and benefit from:}

- Convenient online submission

Rigorous peer review

- Open access: articles freely available online

- High visibility within the field

Retaining the copyright to your article

Submit your next manuscript at $\boldsymbol{\Delta}$ springeropen.com 